bioRxiv preprint doi: https://doi.org/10.1101/2020.05.14.096032; this version posted July 29, 2020. The copyright holder for this preprint (which was not certified by peer review) is the author/funder, who has granted bioRxiv a license to display the preprint in perpetuity. It is made available under aCC-BY 4.0 International license.

\title{
Mycobacteria inhibit neutrophil recruitment to avoid neutrophil-assisted killing by macrophages
}

Sergio Candel, Lalita Ramakrishnan

The authors are withdrawing the paper because we find some discrepancies in the experimental protocols as reported in the manuscript. Therefore, the authors do not wish this work to be cited as reference for the project. If you have any questions, please contact the corresponding author. 